\title{
Cultivation and Biological Characterization of Chicken Primordial Germ Cells
}

\author{
Meng Ji ${ }^{1}$, Wei-jun Guan ${ }^{1}$, Yu-hua Gao ${ }^{1}, \mathrm{Lu} \mathrm{Li}^{2}$, Chun-yu Bai ${ }^{1}$, Yue-hui Ma ${ }^{1}$ and Xiang-chen \\ $\mathbf{L i}^{1 *}$ \\ ${ }^{1}$ Institute of Animal Science; Chinese Academy of Agricultural Sciences. ${ }^{2}$ College of Animal Science and Technology, \\ Agricultural University of Hebei; China
}

\begin{abstract}
The purpose of this work was to investigate the isolation, culture process of chicken gonadal primordial germ cells (PGCs) and study their biological characterization. PGCs were harvested from 5.5-day-old chicken embryonic genital ridges and explanted onto chicken embryonic fibroblasts (CEFs). The results showed that the primary cultivation of chicken PGCs on their own gonadal stroma cells were better than CEFs at first two days for reproduction. The conditioned media supported the growth and colony formation of PGCs for a prolonged time in vitro and maintained a normal diploid karyotype, which were positively stained by alkaline phosphatase (AKP), periodic acid Schiff (PAS) and reacted with anti-SSEA-1, SSEA-3, Oct4, Blimp1 and Sox2. Real-time PCR showed that they expressed the stage specific genes CVH, Blimpl and Dazl, the stem cell specific genes Sox2, Pouv and Nanog. They also formed the embryoid bodies (EBs). These results suggested that the chicken PGCs cultured in vitro not only had strong selfrenewal ability, but also had the potential capability of multi-lineage differentiation.
\end{abstract}

Key words: Chicken, Primordial germ cells, Biological characteristics, in vitro

\section{INTRODUCTION}

Primordial germ cells (PGCs) arise early in embryogenesis and migrate to the germinal crescent region at stage 4 , and then enter the developing blood vascular system (Naito et al. 2015). It is precursors of the male and female gametes and develops into sperm, or egg cells (Nieuwkoop and Sutasurya 1979), which carry genetic information through sexual reproduction to future generations (Johnson et al. 2011, Naito et al. 2015). It is a pluripotent stem cell resource that has been discovered after embryonic carcinoma cells (ECCs), teratocarcinoma stem cells (TSCs) and embryonic stem cells (ESCs) (Matin et al. 2004, Nayernia et al. 2004). Under the combined effect of growth factors and feeder cell layer, PGCs proliferate and develop for long-term and maintain undifferentiation for embryonic Germ Cells (EGs), just like the state of embryonic stem cells with totipotency of developmental potential. Establishment of the EG for the study of germ cell development and looking for new effective carrier for genetically modified animal operations have great value (Matsui et al. 1992, Resnick et al. 1992). The first bona fide germ cells, the PGCs, leave the epiblast with the extraembryonic mesoderm at the posterior primitive streak, and a group of around 40 PGCs locates at the base of the allantois (Mintz and Russell 1957). These cells successively pass around provisionally into the bloodstream during the stages 13-15 and then migrate to the gonads and differentiate into female or male gametes (Kuwana and Rogulska 1999, Naito et al. 2015). However, getting the PGCs are restricted. Chicken as an

\footnotetext{
*Author for correspondence: xcli863@126.com
} 
acceptance model organism (Cogburn et al. 2007) have advantages of population distribution and samples can be obtained easily. PGCs have been obtained mainly from germinal crescent (Petitte et al. 1990, Park and Han 2012) and embryonic blood (van de Lavoir et al. 2006, Macdonald et al. 2010, Miyahara et al. 2014, Naito et al. 2015). However, their numbers have been quite limited (Park et al. 2003) and couldn't provide sufficient materials for the transgenic manipulation (Shiue et al. 2009). Therefore, chicken PGCs from embryonic gonad and long-term in vitro culture could be adequate resource for genetic manipulation.

Several studies have been made on chicken PGCs since Dubois reported it in 1969 (Dubois 1969). Allioli et al. (1994) reported that chicken PGCs isolated from the gonads could proliferate in vitro for several days with three-culture system, respectively. Park and Han (2002) established a long-term in vitro culture system for chicken gonadal PGCs. They isolated PGCs from the undifferentiated gonads of stage 28 chicken embryos and maintained their specific characteristics for up to two months in vitro.

The purpose of this work was to investigate the isolation, culture process of chicken gonadal primordial germ cells (PGCs) and study their biological characterization.

\section{MATERIAL AND METHODS}

\section{Experimental animals}

All the animal procedures were approved by the Institutional Animal Care and Use Committee of Chinese Academy of Agricultural Sciences. Chicken embryos were provided by the Experimental Animal Base Institute of Animal Sciences, Chinese Academy of Agricultural Sciences, Beijing. The use of animals in research and all experimental procedures involving chicken embryos were conducted in accordance with the guidelines established by the Institutional Animal Care and Use Committee at the University of Medicine and Dentistry of New Jersey-Robert Wood Johnson Medical School.

\section{Preparation of CEFs}

Fibroblasts were isolated from chicken embryos in incubated eggs for eight days, and cultured in Dulbecco's modified Eagle's medium (DMEM,

Gibco) with high glucose containing $10 \%$ fetal bovine serum (FBS, HyClone), then treated with 10 $\mu \mathrm{g} / \mathrm{mL}$ Mitomycin-C (Roche) for $2 \mathrm{~h}$ after-third generation. CEFs were used as the feeder cells for PGCs and were rinsed with $\mathrm{Ca}^{2+}$ and $\mathrm{Mg}^{2+}$ free PBS five times (Hong, Moon et al. 1998).

\section{Isolation and in vitro culture of chicken PGCs}

Fertile eggs were incubated at $38^{\circ} \mathrm{C}$ and $50 \%$ humidity for 5.5 days. Gonads of the chicken embryos developed at stage 28 (Hamburger and Hamilton 1951), were isolated using stereoscopic microscope, then embryonic gonadal tissues were collected and dissociated with $0.125 \%$ trypsin$0.02 \%$ EDTA. After neutralized with DMEM containing $10 \%$ FBS, the gonadal cells were collected by centrifugation.

The precipitated cells were re-suspended in PGCs cell culture medium, which consisted of DMEM medium replenished with 10\% FBS (Gibco, New York, USA), 2\% chicken serum and supplemented with $10 \mathrm{ng} / \mathrm{mL}$ of human stem cell factor (hSCF; Pepro Tech, London, UK), 10 units/mL of leukemia inhibitory factor (LIF; Pepro Tech, London, UK), $20 \mathrm{ng} / \mathrm{mL}$ of human basic fibroblast growth factor (bFGF; Pepro Tech, London, UK), $1 \times$ penicillin/streptomycin (Life Technologies). Cell suspensions were seeded into 6-well culture plates with CEFs as feeding layer (Choi et al. 2010) at a density of $1 \times 10^{4} /$ well, and cultured at $37.5^{\circ} \mathrm{C}$ in $5 \% \mathrm{CO}_{2}$. The PGCs colonies were dissociated and moved into fresh plates with CEFs using trypsinEDTA treatment for subculture (Liu et al. 2014).

\section{PAS staining and alkaline phosphatase activity assay}

For PAS staining, the cell colonies of the cultured chicken PGCs were fixed with $4 \%$ paraformaldehyde for $20 \mathrm{~min}$ and washed $3 \times 5 \mathrm{~min}$ with PBS. The cell colonies were then submerged in periodic acid solution (Sigma-Aldrich) for $5 \mathrm{~min}$ at room temperature. After washing twice with PBS, the cell colonies were immersed in Schiff's solution (Sigma-Aldrich) for $15 \mathrm{~min}$ at room temperature. Then PAS-stained PGC colonies were observed under an inverted microscope after washing twice with PBS. AKP activity was detected by AKP substrate kit (Sigma-Aldrich) according to the manufacture's instruction. Images were captured with a computer-assisted video camera (IX-71 inverted research microscope, Olympus, Japan).

\section{Karyotyping}


The chicken PGCs were incubated in $0.5 \mu \mathrm{g} / \mathrm{mL}$ colcemid (Karyomax, Invitrogen) at $37.5^{\circ} \mathrm{C}$ in $5 \%$ $\mathrm{CO}_{2}$ for $5 \mathrm{~h}$, then the chicken PGCs were dissociated with $0.125 \%$ trypsin- $0.02 \%$ EDTA. The cells were then centrifuged and re-suspended in $0.075 \mathrm{M} \mathrm{KCl}$ solution at $37^{\circ} \mathrm{C}$. After $30 \mathrm{~min}$, the cells were centrifuged at $200 \mathrm{~g}$ for $8 \mathrm{~min}$ and the pellet was fixed in 3:1 methanol: glacial acetic acid. For metaphase analysis, the cell suspension was dropped on the frozen glass slides, stained with Giemsa (Amresco, Solon, OH, USA) and analyzed for the six pairs of macro-chromosomes and the sex chromosomes. At least 20 metaphase spreads were counted for every chicken PGC passage.

\section{Immunocytochemistry staining}

For immunocytochemical analysis, the chicken PGCs were fixed in $4 \%$ paraformaldehyde (PFA) in PBS and permeabilized with $0.4 \%$ Triton/X-100. Blocking with $10 \%$ goat serum was performed for
$1 \mathrm{~h}$ prior to the incubation with primary antibodies. The cells were incubated with primary antibodies ant-SSEA-1, SSEA-3, BLIMP1, Oct4 and Sox2 at $4^{\circ} \mathrm{C}$ overnight, followed by with goat anti-rabbit Alexa Fluor 594 (red) -labeled secondary antibody (A11072, Invitrogen) for $1 \mathrm{~h}$. DAPI was used to label the cell nuclei, and images were captured with a fluorescence microscope (Nikon TE-2000-E inverted microscope, Japan).

\section{RT-PCR analysis}

Total RNA was extracted from the PGC colonies at third passage using TRIzol (Invitrogen). After DNase I treatment to remove the potential contamination of genomic DNA, $2.0 \mu \mathrm{g}$ of total RNA were reverse transcribed into cDNA using an RNA PCR Kit (AMV) Ver 3.0 (Takara, China). The gene expression analysis was detected by $\mathrm{ABI}$ StepOnePlus real-time

Table 1 - The primer information for PGC identification.

PCR thermal cycling instrument (USA). The stage specific genes CVH, BLIMP1 and Dazl, the stem cell specific genes Sox2, Pouv

\begin{tabular}{|c|c|c|c|c|}
\hline Gene name & Primer sequences & Circles & Product length (bp) & $\operatorname{Tm}\left({ }^{\circ} \mathrm{C}\right)$ \\
\hline \multirow[t]{2}{*}{ CVH } & F: 5'- ATGATGAATGTGCTGTTGAG-3' & 35 & 149 & 50 \\
\hline & R: 5’- AGGAATGCTGTGCTTCTG-3' & & & \\
\hline \multirow[t]{2}{*}{ BLIMP1 } & F: 5'- ACCTCACATTCCAGAAGAC-3' & 35 & 108 & 50 \\
\hline & R: 5'- GAAGGACTTGGTGTAGTAGAT-3' & & & \\
\hline \multirow[t]{2}{*}{ DAZL } & F: 5'- CAATATGGTACTGTGAAGGAG-3' & 35 & 126 & 50 \\
\hline & R: 5'- GACACTGATCTGTGATTCTAC-3' & & & \\
\hline \multirow[t]{2}{*}{ SOX2 } & F: 5'- GTCACCTCCTCGTCTCAT-3' & 35 & 140 & 51 \\
\hline & R: 5'- GCACTCTGGTAGTGTTGG-3' & & & \\
\hline \multirow[t]{2}{*}{ POUV } & F: 5'- CAAGGACCTCAAGCACAA-3' & 35 & 89 & 50 \\
\hline & R: 5'- TGAACATCTTCCCATAGAGC-3' & & & \\
\hline \multirow[t]{2}{*}{ NANOG } & F: 5'- GCCTGTATCCGTTCATGG-3' & 35 & 140 & 51 \\
\hline & R: 5'- GTCATAATCCACATTGGTAGAG-3' & & & \\
\hline \multirow[t]{2}{*}{ GAPDH } & F: 5'-GAGGGTAGTGAAGGCTGCTG-3' & 35 & 113 & 51 \\
\hline & R: 5'-CATCAAAGGTGGAGGAATGG-3' & & & \\
\hline
\end{tabular}

and Nanog were detected (the primers information shown in Table 1), the PCRs reaction were performed by the PCR Master Mix Kit (Promega, USA), and the PCR products were visualized by electrophoresis on $2.5 \%$ agarose gels.

\section{Embryoid body formation}

The three passages of PGCs were used for EBs formation. PGC cell colonies were digested with $0.125 \%$ trypsin- $0.02 \%$ EDTA for $1 \mathrm{~min}$ at $37^{\circ} \mathrm{C}$, gently broken into single cell and cultured on a gelatin-coated dish in suspension for two weeks in DMEM supplemented with $15 \%$ FBS. The medium was changed every two days. The cultures were maintained at $37.5^{\circ} \mathrm{C}$ in a humidified $5 \% \mathrm{CO}_{2}$ incubator.

\section{Statistical analysis}

Statistical analyses of the data were performed with a one-way ANOVA, followed by the TukeyKramer honestly significant difference (HSD) test for the three sets of results. AP-value of less than 0.05 was considered significant. Statistical analyses were done with a $\mathrm{JMP} \circ, \mathrm{R}$ Statistical Discovery Software (SAS Institute, Cary, NC).

\section{RESULTS}


Culture and characterization of chicken PGCs

In this study, the primary cultivation of the chicken PGCs were plated together with their own gonadal stroma cells. The PGCs formed cell colonies after two days (Fig. 1A). On the contrary, directly cultured chicken PGCs with CEFs formed PGCs colonies less efficiently (Fig. 2). After subculture of the single PGCs were attached to the surface of CEFs and grown up into small cell colonies after seeding for $24 \mathrm{~h}$ (Fig. 1B), the small cell colonies turned to bigger cell clusters after three days (Fig. 1C). The PGCs were cultured for five weeks and treated for subculture on an average of three days. The PGCs cell morphology and growth characteristics are the basis identification of PGCs (Meyer 1964). The size of PGCs, large amounts of glycogen granules in the cytoplasm and large nuclei are bigger than somatic cells. Therefore, PAS stained of PGCs can be set apart from somatic cells (Jung et al. 2005). The presence of alkaline phosphatase activity is an important indicator for the cells in the undifferentiated state, like ES cells
(O'Connor et al. 2008). Undifferentiated PGCs were with high AKP activity, hence the differentiation of PGCs cultured in vitro by AKP staining could be examined. This study showed that PGCs were stained mauve with AKP staining and red by PAS staining (Fig. 1E-F).

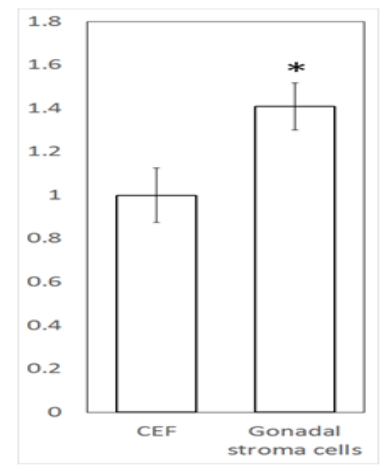

Figure 2 - Colony forming efficiency of PGCs under two different conditions. Under the gonadal stroma cells condition PGCs could form cell colonies more efficiency than the condition of CEF. $(* P<0.05)$.

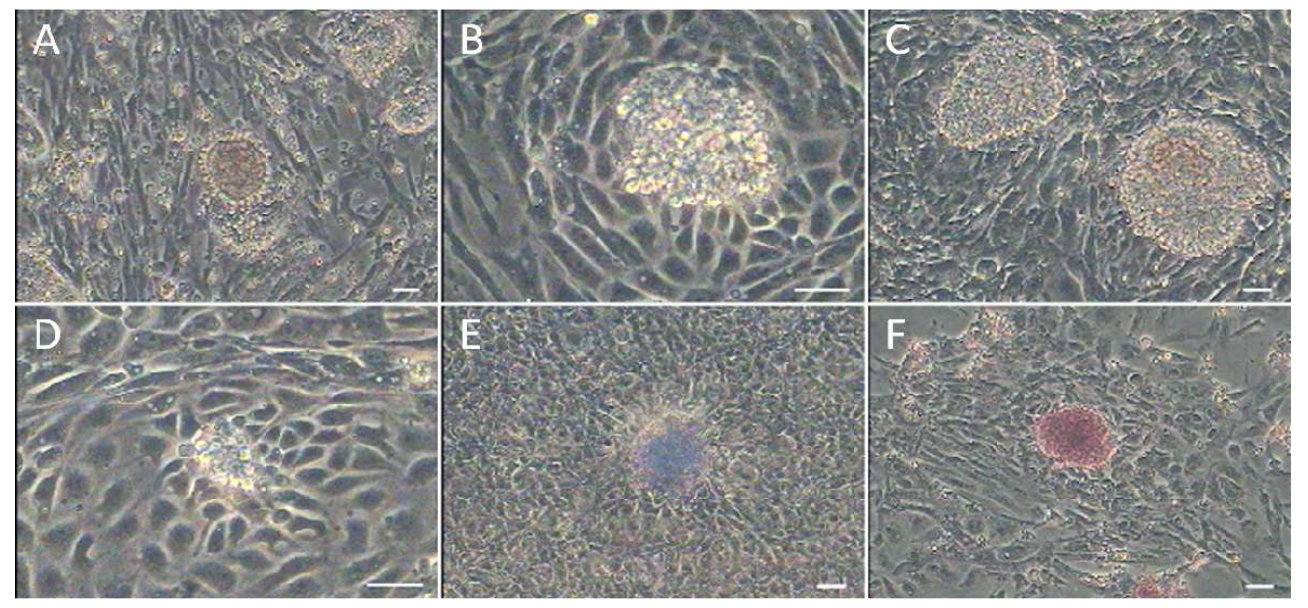

Figure 1 - Morphology of PGCs. (A) On day 2 of primary culture, PGCs had a distinct "colony"' shape. (B) On $24 \mathrm{~h}$ of subculture, PGCs grown up into small cell colonies. (C) On day 3 of subculture, the small cell colonies turned to bigger cell clusters. (D) On day 3 of primary culture, the gonadal stroma cells apoptosis cause PGCs differentiation. (E-F) PGCs were stained mauve with AKP staining and red by PAS staining (scale bar: $100 \mu \mathrm{m}$ ).

\section{Karyotype and chromosome number of chicken PGCs}

The chromosome karyotype was checked in fifth passage. Karyotype analysis revealed that the PGCs were diploid $(2 n=78)$ with nine pairs of macrochromosomes and 30 pairs of microchromosomes (Fig. 3). The sex chromosome type was ZZ or ZW. PGCs karyotype was no variation after subculture.

\section{Immunocytochemistry staining of chicken PGCs} The key PGC genes in humans include NANOS3, BLIMP1, TFAP2C, STELLA, TNAP, KIT, OCT4, and NANOG (Irie et al. 2015). Human ES express cell-surface antigens SSEA-3, SSEA-4, TRA-1-60 and TRA-1-81, while mouse ES cells express SSEA-1 (Henderson et al. 2002). The three passages of PGCs expressed stage-specific surface 
makers SSEA-1, SSEA-3, BLIMP1 and stem cell makers Oct4, Sox2 (Fig. 4).

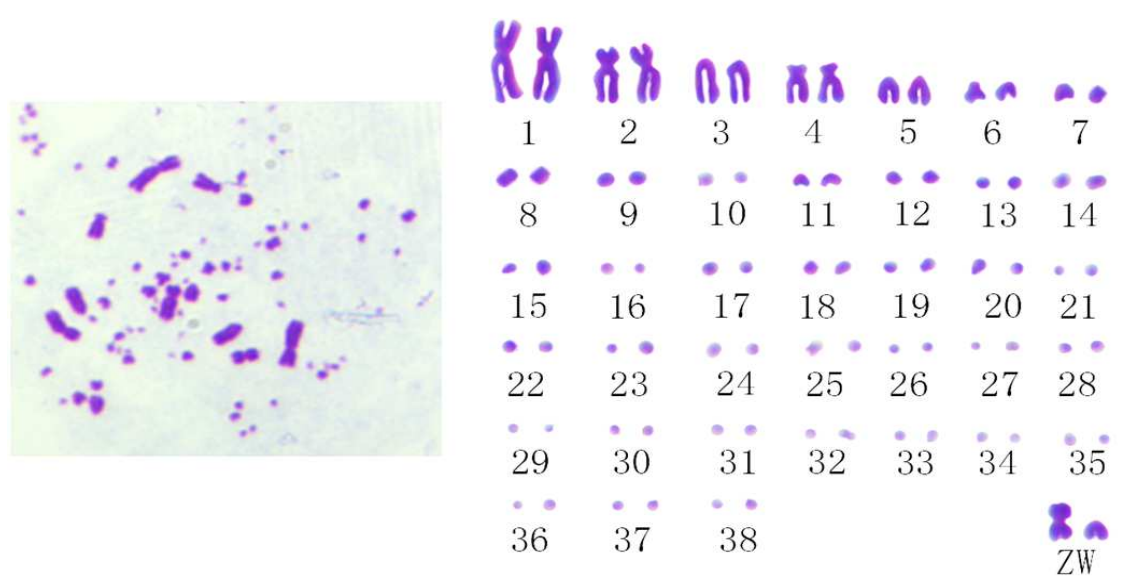

Figure 3 - Chromosome at metaphase (left) and karyotype (right) of chicken PGCs () ZW type. The diploid chromosome number in chicken PGCs was $2 n=78$, consisting of nine pairs of macrochromosomes and 30 pairs of microchromosomes.

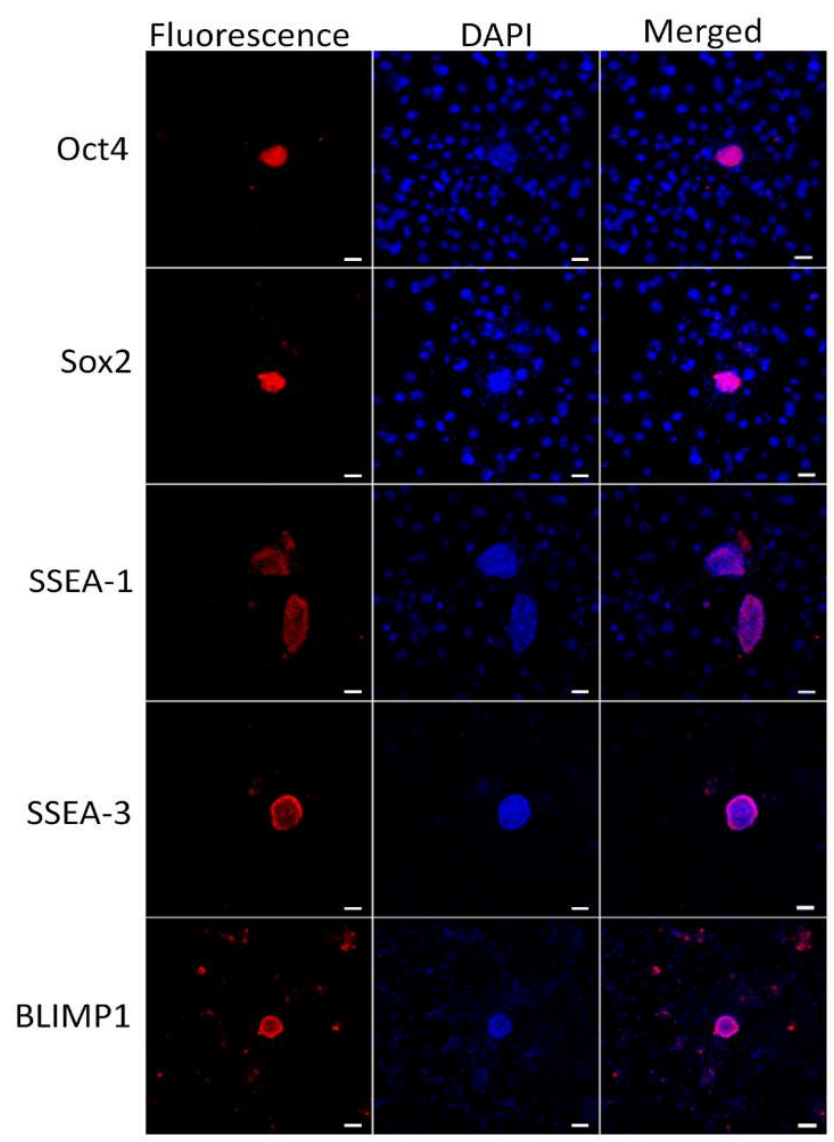

Figure 4 - Surface marker detection of chicken PGCs by immunofluorescence staining. The results show that Oct4, Sox2, SSEA-1, SSEA-3 and BLIMP1 are positively expressed (scale bar: $100 \mu \mathrm{m})$.

RT-PCR for detection of specific gene The analysis of CVH, Blimp1, Dazl, PGCs marker expression results gene, and Sox2, POUV, Nanog, stem cell gene, by 
RT-PCR (Fig. 5) showed that the cell colonies in three passages were PGCs, which were detected for stem cell maintenance.

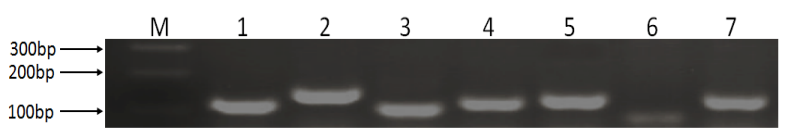

Figure 5 - Detection of PGCs markers by RT-PCR. M: Marker; 1: GAPDH (113 bp); 2: CVH (149 bp); 3: BLIMP1 (108 bp); 4: DAZL (126 bp); 5: SOX2 (140 bp); 6: POUV (89 bp); 7: NANOG (140 bp).

\section{EBs formation}

To induce EB formation from the PGCs, the undifferentiated PGCs at passage three were

removed from the feeder layers and cultured in EB formation flasks with a non-factors medium and a suspension condition. Initially, PGCs were shown in single round cell colonies with a bright refraction (Fig. 6A). After three days, PGCs aggregated gradually and formed simple EBs (Fig. 6B), and two days later, the number of EBs increased (Fig. 6C). After culturing a week, the size of EBs increased (Fig. 6D). On day 10, a single-layer columnar cells were observed at the edge of the suspending EB clusters; the single-layer cell boundary were clear; the cells in the internal parts of the EBs had a trend from open growth to dense growth, and some EBs formed cavities in the center area without any columnar cells (Fig. 6E). At the second week, EBs had a further growth in size, most of them were in round shape as before, but some of them were in irregular shape combined multiple round cell clusters (Fig.6F).

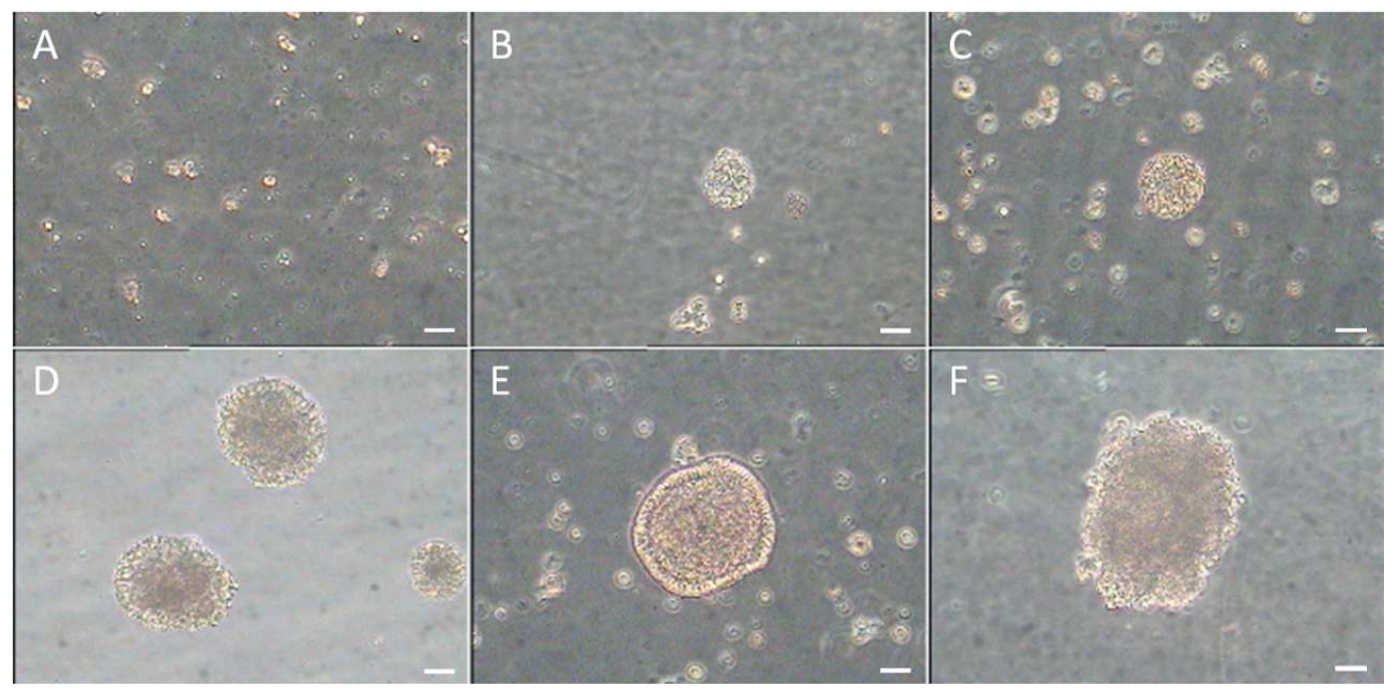

Figure 6 - EBs formation from PGCs. (A) On primary culture, PGCs were in single round cell. (B) After three days PGCs aggregated gradually and formed simple EBs. (C) On day 5 of culture, the number of EBs increased. (D) On a week of culture the size of EBs increased. (E) On day 10, the edge of the EB clusters appeared a single-layer columnar cells. (F) On two weeks of culture, EBs had a further growth in size (scale bar: $100 \mu \mathrm{m}$ ).

\section{DISCUSSION}

The primary culture of the chicken PGCs were plated together with their own gonadal stroma cells; cultured PGCs had a distinctive cellular morphology consisting of a large nucleus and a cluster of large vacuoles present in the cytoplasm, ground round PGCs cluster with less differentiated cells from the PGCs. There were gonadal stroma cells, which provided adequate nutrition to the
PGCs at the first two days just like in vivo, but their supply was not up with the PGCs for a long time. After three days, the gonadal stroma cells apoptosis led to the rupture of feeder layer and caused PGCs differentiation.

Previous studies (Yang and Petitte 1994, Choi et al. 2010) have shown that CEFs provide growth environment and signals for the PGCs attachment of adherent growth and secreted growth factor inhibited their differentiation, as feeder layer was a 
good choice. The primary cultured and $1^{\text {st }}$ passage of CEFs act as feeder without highly pure fibroblast, but higher than four passages fibroblast, easy chromosome anomalies, may decline the functions as feeder layer. On the other hand, the quality of feeder layer cells have a great relationship with the time of Mitomycin-c treat, rinsing Mitomycin-c cleanly, or not and proper seeding density. High-density feeder layer cells not only produce contact inhibition of the normal cells to reduce the energy, but also make excessive culture fluid drain. Low-density fibroblasts cannot contiguous to form feeder single-layer. Hence, three passage CEFs was used at a density of $1 \times$ $10 \%$ well, washing with PBS eight times after Mitomycin-c treatment as feeder layer. The chicken PGCs could be maintained for over 10 passages in an undifferentiated state on a feeder layer made with well-grown CEFs.

Twice diploid karyotype is the prerequisite for the cell growth and functioning. Chickens have nine pairs of macrochromosomes and 30 pairs of microchromosomes with sex chromosomes $\mathrm{Z}$ and W (Pollock and Fechheimer 1976, Fechheimer 1990). In this study, the chromosome karyotype of fifth passage was examined, which showed that chicken embryos PGCs were able to maintain a normal chromosome after subculture of five passages.

In this study, the chicken PGCs could propagate in vitro for five weeks in the culture medium replenished with hSCF, LIF and bFGF. The chicken PGCs expressed Cvh, Blimp1 and Dazl (van de Lavoir et al. 2006a), and the transcription factors POUV, Nanog and Sox 2 acted cooperatively to maintain the pluripotency in both humans and mouse ESC (van de Lavoir et al. 2006b). Finally, the formation of EBs in vitro shoed that the chicken PGCs were potentially capable of multi-lineage differentiation.

\section{CONCLUSION}

The results of this study confirmed that the cells derived from stage 28 chickens genital ridge exhibited a morphology and epitope profiles that were similar to those of duck ES and EG cells after extended periods in culture. The primary cultivation of chicken PGCs on their own gonadal stroma cells were better than CEFs at first two days. The chicken PGCs cultured on the CEFs were successfully grown. CEFs could be used to support the growth of PGCs in vitro for five weeks. The chicken PGCs could form EBs in vitro.

\section{ACKNOWLEDGMENTS}

This work was supported by The National Natural Science Foundation of China (31472099). This work was also supported in part by The Agricultural Science and Technology Innovation Program (ASTIP) (cxgc-ias-01).

\section{REFERENCES}

Choi JW, Kim S, Kim TM, Kim YM, Seo HW, Park TS, et al. Basic fibroblast growth factor activates MEK/ERK cell signaling pathway and stimulates the proliferation of chicken primordial germ cells. PLoS One. 2010; 59: e12968.

Cogburn LA, Porter TE, Duclos MJ, Simon J, Burgess $\mathrm{SC}$, Zhu JJ, et al. Functional genomics of the chicken-a model organism. Poult Sci. 2007; 8610: 2059-2094.

Dubois R. [Localization of primordial germinal cells on the non-incubated chicken germ layers]. C R Acad Sci Hebd Seances Acad Sci D. 1969; 2692: 205-208.

Fechheimer N. Chromosomes of chickens. Adv Vet Sci Com Med. 1990; 34: 169-207.

Hamburger V and Hamilton HL. A series of normal stages in the development of the chick embryo. $J$ Morphol. 1951; 881: 49-92.

Henderson JK, Draper JS, Baillie HS, Fishel S, Thomson JA, Moore H, et al. Preimplantation human embryos and embryonic stem cells show comparable expression of stage-specific embryonic antigens. Stem Cells. 2002; 204: 329-337.

Hong YH, Moon YK, Jeong DK and Han JY. Improved transfection efficiency of chicken gonadal primordial germ cells for the production of transgenic poultry. Transgenic Res. 1998; 74: 247-252.

Irie N, Weinberger L, Tang WW, Kobayashi T, Viukov S, Manor YS, et al. SOX17 Is a Critical Specifier of Human Primordial Germ Cell Fate. Cell. 2015; 16012: 253-268.

Johnson AD, Richardson E, Bachvarova RF and Crother BI. Evolution of the germ line-soma relationship in vertebrate embryos. Reproduction. 2011; 1413: 291300.

Jung JG, Kim DK, Park TS, Lee SD, Lim JM and Han JY. Development of novel markers for the characterization of chicken primordial germ cells. Stem Cells. 2005; 235: 689-698.

Kuwana T and Rogulska T. Migratory mechanisms of chick primordial germ cells toward gonadal anlage. Cell Mol Biol (Noisy-le-grand). 1999; 455: 725-736. 
Liu CX, Wang WL, Zhao RY, Wang HT, Liu YY, Wang $\mathrm{SY}$, et al. Isolation, culture, and characterization of primordial germ cells in Mongolian sheep. In Vitro Cell Dev Biol Anim. 2014; 503: 207-213.

Macdonald J, Glover JD, Taylor L, Sang HM and McGrew MJ. Characterization and germline transmission of cultured avian primordial germ cells. PLoS One. 2010; 511: e15518.

Matin MM, Walsh JR, Gokhale PJ, Draper JS, Bahrami AR, Morton I, et al. Specific knockdown of Oct4 and beta2-microglobulin expression by RNA interference in human embryonic stem cells and embryonic carcinoma cells. Stem Cells. 2004; 225: 659-668.

Matsui Y, Zsebo K and Hogan BL. Derivation of pluripotential embryonic stem cells from murine primordial germ cells in culture. Cell. 1992; 705: 841847.

Meyer DB. The Migration of Primordial Germ Cells in the Chick Embryo. Dev Biol. 1964; 10: 154-190.

Mintz B and Russell ES. Gene-induced embryological modifications of primordial germ cells in the mouse. $J$ Exp Zool. 1957; 1342: 207-237.

Miyahara D, Mori T, Makino R, Nakamura Y, Oishi I, Ono $\mathrm{T}$, et al. Culture Conditions for Maintain Propagation, Long-term Survival and Germline Transmission of Chicken Primordial Germ Cell-Like Cells. Journal of Poultry Science. 2014; 511: 87-95.

Naito M, Harumi T and Kuwana T. Long-term culture of chicken primordial germ cells isolated from embryonic blood and production of germline chimaeric chickens. Anim Reprod Sci. 2015; 153: 50-61.

Nayernia K, Li M, Jaroszynski L, Khusainov R, Wulf G, Schwandt I, et al. Stem cell based therapeutical approach of male infertility by teratocarcinoma derived germ cells. Hum Mol Genet. 2004; 1314: 1451-1460.

Nieuwkoop PD and Sutasurya LA. Primordial germ cells in the chordates: embryogenesis and phylogenesis. CUP Archive. 1979.

O'Connor MD, Kardel MD, Iosfina I, Youssef D, Lu M, Li MM, et al. Alkaline phosphatase-positive colony formation is a sensitive, specific, and quantitative indicator of undifferentiated human embryonic stem cells. Stem Cells. 2008; 265: 1109-1116.

Park TS and Han JY. PiggyBac transposition into primordial germ cells is an efficient tool for transgenesis in chickens. Proc Natl Acad Sci U S A. 2012; 10924: 9337-9341.

Park TS, Jeong DK, Kim JN, Song GH, Hong YH, Lim $\mathrm{JM}$, et al. Improved germline transmission in chicken chimeras produced by transplantation of gonadal primordial germ cells into recipient embryos. Biol Reprod. 2003; 685: 1657-1662.

Petitte JN, Clark ME, Liu G, Verrinder Gibbins AM and Etches RJ. Production of somatic and germline chimeras in the chicken by transfer of early blastodermal cells. Development. 1990; 1081: 185189.
Pollock DL and Fechheimer NS. The chromosome number of Gallus domesticus. Br Poult Sci. 1976; 171: $39-42$.

Resnick JL, Bixler LS, Cheng L and Donovan PJ. Longterm proliferation of mouse primordial germ cells in culture. Nature. 1992; 3596395: 550-551.

Shiue YL, Tailiu JJ, Liou JF, Lu HT, Tai C, Shiau JW, et al. Establishment of the long-term in vitro culture system for chicken primordial germ cells. Reprod Domest Anim. 2009; 441: 55-61.

van de Lavoir MC, Diamond JH, Leighton PA, MatherLove C, Heyer BS, Bradshaw R, et al. Germline transmission of genetically modified primordial germ cells. Nature. 2006; 4417094: 766-769.

van de Lavoir MC, Mather-Love C, Leighton P, Diamond JH, Heyer BS, Roberts R, et al. High-grade transgenic somatic chimeras from chicken embryonic stem cells. Mech Dev. 2006; 1231: 31-41.

Yang $\mathrm{Z}$ and Petitte JN. Use of avian cytokines in mammalian embryonic stem cell culture. Poult Sci. 1994; 737: 965-974.

Received: July 04, 2015; Accepted: September 14, 2015. 